\title{
Sensory-Motor Amnesia and Somatic Solutions
}

\author{
Jeong Myung Gim* \\ Myongji University, Yongin, Korea
}

Received: October 10, 2017

Accepted: January 20, 2018

Published online: January 31, 2018

Keywords:

Proprioception

Sensory-Motor Amnesia

Somatics

Chronic muscle contraction
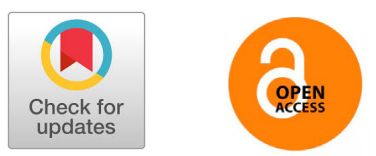

\begin{abstract}
PURPOSE The purpose of this study was to identify the neurophysiological mechanisms of Sensory-Motor Amnesia (SMA) and to understand the clinical basis of Hanna's somatic education as a somatic solution.

METHODS This study mainly focuses on the related literature studies. In order to understand the experiential properties of SMA and to enhance the credibility of the reference to Hanna's solution, the researcher visited the Novato institute developing Hanna Somatic Education 5 times and collected the data.

RESULTS 1) Hanna's discovery of SMA was influenced by Hans Selye's general adaptation syndrome and 'stress' concept in that human physiological functions are not separated from psychological phenomena. At the same time after practical training under Feldenkrais' guide and observing clients from the first-person perspective, he realized the neurophysiological clue in his own practices. 2) SMA is a phenomenon of muscle contraction that occurs when the chronic stress reaction disturbs the autonomic nervous system. When the stress condition persists, it becomes an obstacle of the sensory-motor function in the unconscious area and paralyzes the inherent proprioceptive senses. It not only limits the range of intentional human movements but also acts as a cause of the structural distortion of the body. 3) Based on Alexander's Means-Whereby principle and Feldenkrais' Kinetic Mirroring, he developed a more effective technique, Pandiculation Response, to improve the clinical effectiveness to SMA problem.

CONCLUSIONS Somatic Education is not a process from the third-person observation as the existing medical system but a process of integrating the third-person information centered on the first-person viewpoint, so the empirical basis should be established in a new integrated clinical system dealing with human soma.
\end{abstract}

( T The Asian Society of Kinesiology and the Korean Academy of Kinesiology

\section{서 론}

뇌신경계가 인간의 학습에 관여하고 있다는 사실은 이 미 오래된 상식이다. 특히 학습이 대뇌피질에서 일어나고 있는 점을 들어 그 부위가 발달한 인간을 다른 생명체로 부터 구별한다. 하여 인간의 뇌신경계는 흔히 컴퓨터의 $\mathrm{CPU}$ 에 비유되며 근골격계에 행동명령을 내리는 중추기 관(central nervous system; CNS) 쯤으로 인식된다. 실제로 뇌와 척추로 연결된 뇌신경계는 인간의 인지와 움직임에 서 중추적 역할을 담당한다. 그러나 여기서 ‘중추적'이

*Correspondence: Jeong Myung Gim, Myongji University, Yongin, Korea. E-mail adress: jmgim@mju.ac.kr
라는 말을 컴퓨터에서와 같이 연산작용을 통해 명령주체 가 되는 것으로 생각하면 문제가 생긴다. 신경생리학적으 로 볼 때 $\mathrm{CNS}$ 는 근골격계와 연결되어 학습과 운동을 비 롯한 다양한 기능을 수행하고 있지만, 컴퓨터가 작동하 는 시스템과는 차이가 있기 때문이다. 컴퓨터가 기계적인 원리에 의해 작동한다면 인간의 몸(soma)은 매 순간의 환 경에 적응하며 중추신경계의 변화를 통해 근골격계를 변 화시키는 ‘소마의 원리'에 의해 움직이기 때문이다(김 정명, 2016). 하지만 '소마의 원리'는 학계에서 아직도 탐색의 단계에 머물러 있다. 마음과 몸, 정신과 물질이라 는 이원론적 도식에 익숙한 현대인들은 몸기반의 '소마 의 원리'에 의해 이루어지는 소마교육의 실체를 이해하 지 못하고 과학의 영역 밖에서 일어나는 '주관적' 또는 
'신기한' 사건 정도로 생각하는 경향이 있다. 이에 소 마교육이 과학적 바탕에서 이루어지고 있다는 근거로서

Thomas Hanna(1988)는 SMA(Sensory-Motor Amnesia)라는 만성근수축의 신경생리학적 기전을 보여주고 이를 해결 하는 과정에서 뇌신경 계가 근골격계에 어떠한 방식으로 관여하고 있는지 자세히 들여다 볼 필요가 있다고 보았 다.

이에 본 연구는 만성근수축 상황에서 야기되는 감각운동 마비(sensory-motor amnesia; SMA)의 신경생리학적 기전을 확인하고 이에 대한 회복교육인 Hanna의 몸학교 육(somatic education)의 임상운동적 기반을 알아보려는 것을 목적으로 다음과 같은 연구문제를 설정하였다.

첫째, 철학자였던 Thomas Hanna는 어떻게 심리생리적 문제인 감각-운동 마비(SMA)를 발견하게 되었는가?

둘째, 만성근육수축과 함께 나타나는 SMA의 신경 생리 학적 기전은 어떻게 형성되는가?

셋째, SMA의 회복에 초점을 둔 Thomas Hanna의 임상 운동적 대안은 무엇인가?

이 연구는 주로 관련문헌연구가 중심이 되고 있으나 $\mathrm{SMA}$ 의 체험적 속성의 이해와 몸학적 대안에 대한 레퍼 런스의 신뢰성을 높이기 위해 연구자가 미국 노바토 연구 소 HSE(Hanna Somatic Education) 워크숍 프로그램에 5차 례 직접 참여하는 방문연구를 실시하였다.

\section{감각운동 마비[Sensory-Motor Amnesia: SMA] 의 발견경로}

SMA가 발견된 것은 치료를 전문으로 하는 의료연구자 에 의해서도 아니고 운동을 전문으로 연구하는 체육학자 에 의해서도 아니고 인간의 삶과 몸을 탐구하던 철학자에 의해서였다. 인간의 자유에 관심을 가지고 신학과 철학을 공부하던 Thomas Hanna (1928-1990)는 시카고 대학에서 실존주의 현상학으로 박사학위를 받은 후, 1970년 '몸의 혁명(Bodies in revolt: A primer of somatic thinking)'이라 는 책 속에 서양 근대사에서 몸(soma)에 대한 사고의 전환 이 이루어져 온 철학적, 과학적 배경을 살폈다. 즉 몸은 대 상으로 뿐만 아니라 주체로서의 존재기반이 될 수밖에 없 음을 알리고 몸을 정신이나 마음과 분리시키는 이원론적 허구성에 쐐기를 박았다(Hanna, 1970). 이어 플로리다 대 학에서 철학교수를 하면서 몸을 억압하고 있는 현상에 관 심을 갖고, 같은 대학 의 대에서 몸에 대한 의학적 관점을
연구하였다. 그는 의학계에도 마음-몸, 정신-물질의 이원 적 편견이 여전히 만연되어 있음을 발견하고 Hans Selye (1907-1982)의 연구와 Moshe Feldenkrais (1904-1984)의 교 육기법에 기초하여 몸학(Somatics)이라는 일원론적 학문 의 필요성을 제기하기에 이른다. 현재 SMA는 몸학은 물 론 이러한 접근을 유용하고 있는 제반 운동치료교육의 핵 심 개념으로 등장하고 있다. 따라서 SMA에 대한 정확한 개념의 이해를 위해서는 의사였던 Hans Selye와 Thomas Hanna의 실기교사였던 Fedenkrais의 기법부터 짚어볼 필 요가 있다.

\section{Hans Selye의 영향}

Hans Selye는 '스트레스’라는 개념을 만든 내분비 전 공의사로서 인간의 심리적 현상과 생리적 기능이 분리되 어 있지 않음을 밝힌 학자로 유명하다. 그가 스트레스라 는 개념에 처음 관심을 갖게 된 것은 의학도 시절 다양한 질병으로 고통 받는 사람들이 유사한 증상을 보이거나비 슷한 고통을 호소하고 있다는 점을 알고부터이다. 사실 스트레스라는 용어는 그 이전에도 물리학계에서 물질이 최초 사이즈로 회복하는 탄성(elasticity)의 의미로 이미 쓰 이고 있었는데, Selye는 이 사실을 모르고 있었다(Rosch, 2017). 8가지 언어를 유창하게 구사한 것으로 알려진 헝가 리 출신의 Selye는 특히 고대 언어가 가지고 있는 단어의 중의성에 착안하여 스트레스라는 용어를 사용하게 된 것 으로 보인다. 고대 그리스에서 히포크라테스가 '질병' 의 의미로 사용한 pathos(suffering)는 동시에 ponos(toil)를 뜻하기도 하였는데 그것은 정상으로 회복하려는 몸의 수 고라는 긍정적인 의미도 함께 있었다. 또한 한자로 스트 레스를 번역한다면 위기(危機)라는 용어가 적합할 터, 이 또한 외부의 위험에 대한 기회라는 긍정적 의미로 해석 될 수 있다. 결국 스트레스는 우리 몸에 압력을 가하는 외 부요인들(stressor)에 대한 몸의 대응이란 의미를 갖고 있 는 셈이다. 따라서 그것은 그 대응기전에 따라 긍정적, 부 정적으로 나타날 수 있다(Selye, 1978). Thomas Hanna는 우 리 자신의 태도나선택에 따라서 스트레스를 경감시킬 수 있는 것은 이른 바 몸학적 관점에서 가능하다고 보았다.

심신일원론자였던 Thomas Hanna는 Selye가 제기한 일 반 적응 증후(general adaptation syndrome)과 스트레스 개 념의 용례를 들여다보면서 몸에서 일어나는 심리적.생 리적 장애가 스트레스와 밀접한 관계가 있음을 알았다. Hanna가 SMA (sensory- motor amnesia)를 찾아낸 것은 몸 
을 주체적 일자 관점에서 해석하는 과정에서 이룬 결과 로 볼 수 있다. 몸을 삼자 관점에서 치료 또는 연구대상으 로 파악하는 의사와 물리치료사, 또는 생리학자의 입장 에서는 환자의 몸에서 일어나는 주관적, 심리적 현상까지 관찰하기는 어렵다. 환자가 호소하는 통증을 눈에 보이 는 증상과 관련한 측정치만으로 진단하고 처방해온 의사 의 입장에서 환자의 심리적 부분까지 모두 고려하기 어렵 기 때문이다. 사실 SMA가 우리 몸에서 발생하는 원인은 다름 아닌 이러한 주관적 스트레스 상황과 밀접한 관계 가 있고, 그래서 그것은 국소근육질환(regional muscular illness)이라는 의료적 난제로 취급되어 온 것이다(Hanna, 1990). Hanna는 SMA를 스트레스로 인한 근육의 불수의적 수축에 의해 일어나는 감각-운동계의 통합적 장애로 보 고 접근하였고 생리적인 문제와 심리적인 상황이 통합된 일자 관점으로만 문제해결의 단서를 찾을 수 있었다. 이 에 Hanna는 Selye를 몸학의 지평을 연 과학자요 임상의로 평가하고 있다(Hanna, 1990).

\section{Moshe Feldenkrais의 기능통합과 움직임을 통한 자각}

Feldenkrais는 Selye와 거의 동시대 인물이지만 두 사람 은 전혀 다른 세계를 살았다. 단지 Thomas Hanna가 몸학 (Somatics)을 일으킬 때 자신에게 가장 영향을 준 인물들 로 꼽았을 뿐이다(Hanna, 1988). 러시아에서 태어난 유태 인 Feldenkrais는 이후 이스라엘, 프랑스, 영국 등에 거주하 면서 때마다 놀라운 업적을 남겼으며 특히 생애 후반에는 동양적 사고와 서양과학의 결합을 통해 움직임 기반치유 의 기틀을 마련하였다고 평가된다. 핵물리학자였던 그는 퀴리(Juliot-Curie)박사가 노벨물리학상을 받을 당시 수석 연구원이었다(도소은, 2017). 또한 그는 유도를 배우는 과 정에서 터득한 동양 정신과 움직임 기법을 가지고 프랑 스에서 유럽 최초의 도장을 열고 유도에 관한 책도 저술 했다. 축구를 좋아하던 그가 자신의 무릎부상으로 문제 가 생기자 움직임의 신경생리학적 메커니즘을 본격적으 로 연구하여 이른 바 Feldenkrais 요법이 만들어졌다. 움직 임을 통한 자각(awareness through movement; ATM)과 기 능통합(functional integration; FI) 프로그램은 그 결정체로, Thomas Hanna는 바로 Feldenkrais 요법을 바탕으로 본격 적 바디워커(body-worker)의 길을 시작하고 몸학이라는 신과학의 지평을 열었다.

주로 그룹레슨으로 이루어지는 ATM의 경우는 사람 들에게 간단한 움직임을 말로 주문하고, 사람들로 하여
금 움직임의 결과 나타나는 감각 피드백에 주의를 기울 이도록 하는 훈련으로 이루어진다. 감각 피드백에 주의 를 기울이다보면 움직임을 제한하거나 방해하고 있는 부 분이 점차 선명하게 자각되기 시작하면서 근육이나 인대 에 퍼져 있던 고유수용감각 (proprioceptive senses)이 되살 아나게 된다(Feldenkrais, 1990). FI로 불리는 개인레슨에서 는 주의력을 동반한 관찰과 수작업을 통해서 움직임을 제 한하는 장애환경요소를 찾아내고 이에 대한 적응력을 높 일 목적을 가지고 학습자의 주체적 자각 능력을 향상시킨 다. 하여 사람들은 이 레슨을 통해 스스로 만들어내는 움 직임에 대한 자각과 자유도를 높임과 동시에 자아 이미지 까지 확장시킴으로써 선택할 수 있는 움직임의 레퍼토리 를 넓힌다. 또한 Feldenkrais 요법은 움직임의 의도와 결과 를 놓고 일어나는 교사와 학습자 간의 대화가 그 핵심에 있다. 끊임없는 질문을 던지면서 감각각성수준의 상태를 이해해 나가는데 있어서 언어와 움직임에 대한 인지적 연 결은 이 요법의 주요 요소가 된다. 이점에 있어서는 아마 도 유태인 토론학습법 ‘하부루타' 의 방법론이 일부 응용 된 것으로 보인다.

\section{Thomas Hanna의 SMA}

1975년 Thomas Hanna는 Feldenkrais에게 배운 기법을 바탕으로 심리학자이며 신경 생리학자이던 그의 아내 Eleanor Criswell과 함께 세운 노바토연구소(Novato Institute) 를 중심으로 이른바 몸학회(Somatics Society)를 조직했다. 그 이듬해부터는 ‘Somatics'라는 전문학술지를 발간하게 된 것은 바로 의도적 움직임을 방해하는 불수의적 만성 근육수축이 감각-운동을 관장하는 신경 계 장애와 관계되 어 있음을 이해하고 나서 시작된 것이다. 무릎부상이라 는 개인적인 이유로 신경계를 연구하던 Feldenkrais가 FI 를 개발해 낸 것으로 보면 만성근육수축에 대해 어느 정 도 알고 있었던 것으로 추정된다. 그러나 그는 문제의 원 인이나 정체를 파악하기보다 당면한 부상을 해결하는 데 초점을 맞추고 있었던 탓에 FI가 작동하는 메커니즘을 원 리적으로 설명해내지는 못했다. 하여 과학자였던 그였 지만 레슨에서는 과학적이었다기보다 권위적 오라가 늘 따라 다닌 신비주의적 색채를 갖고 있었다(Hanna, 김정 명역, 2013; Hanna, 1979). 그와는 대조적으로 철학자였던 Thomas Hanna는 FI가 실현되고 있는 상태의 몸에 대한 과 학적 탐구를 위해 신경생리학적 탐구를 계속하였다. 마침 내 그는 각종 스트레스로 인하여 무의식 상태에 들어 있 
는 근육의 만성수축 현상이 갖가지 만성적 성인병의 원인 이 되고 있음 밝혀내면서 그 현상이 신경계의 감각-운동 기전의 문제임을 확신하게 되었다. 그는 ‘몸학이란 무엇 인가'(Hanna, 1986)라는 제목의 첫 번째 논문에서 SMA 를 처음 공식용어로 사용하였고 삼자관점의 의학이나 생 물학, 물리요법, 기타 사물 또는 대상으로만 생명체를 다 루고 연구하는 분야에서는 그것이 어째서 밝혀지기 어 려운지를 설명하였다. 1988년 그는 'Somatics'라는 제 하의 저술에서 SMA가 사람의 몸을 어떻게 왜곡하고 신 체적, 심리적 장애를 일으키는지 상세히 소개하고 있다 (Hanna, 1988). Hanna가 세상을 떠나기 직전에 쓴 것으로 판단되는 논문인 '몸학: 건강분야를 개척할 새 임상학 문'에서는 SMA와 관련되어 과거 현장의 소마교육자들 이 이루어 놓은 업적들을 체계적으로 논의 하면서 SMA 진단이론을 발표하고 의료계에 문을 두드리는 작업을 끝 으로 세상을 떠났다(Hanna, 1990). 이 후 SMA는 그의 부인 인 Eleanor Criswell과 그의 동료, 후계자들을 중심으로 연 구되었고 신경과학과 비침투적 영상기법의 발달로 그 정 체가 조금씩 확인되고 있는 실정이다.

\section{SMA의 신경생리학적 기전}

몸과 마음의 통합, 소마(soma)에 대한 Hanna의 신념이 찾아낸 대표적 결산물은 신경근육계의 문제인 SMA이다. 그가 몸학을 제창한 후 뇌의 기전에 관하여 특별한 관심 을 보이며 신경과학의 시대를 예언한 것은 우연이 아니 었다. 앞에서 SMA의 발견 역사를 밝힌 이유는 그것이 의 료적 관점에서 감각의 메커니즘을 다루는 신경학적 연구 나 운동의 생리학적 연구에서 나온 것이 아니라 이 둘과 결합된 몸학적 관점에서 비롯되었음을 강조하기 위해서 였다. 하여 SMA는 일자관점에서 감각과 운동이 분리되 지 않은 하나의 신경생리학적 피드백 회로를 형성하고 있 음을 전제로 이해할 필요가 있다. 몸과 마음, 운동과 감각, 행위와 사고를 분리해서 바라보는 삼자의 시각으로는 다 가가기 어려운 것이 바로 일자의 몸학적 관점이기 때문 이다.

개인의 삶에서 SMA가 생겨나는 시점은 정확히 알기 어렵다. 그러나 의도적 움직임이 줄어들고 일상적인 각성 능력과 움직이는 방법까지 희미해지면 감각-신경 망각이 일어나기 시작하는 것은 사실이다. 신체적 움직임은 두 뇌는 물론 온 몸의 신경망을 활성화하고 몸 전체를 학습
의 도구로 만들지만 그것이 습관과 같이 무의식의 영역으 로 들어 갈 때는 의식적 통제를 벗어난다. 그래서 SMA가 스트레스와 이로 인한 무의식적 움직임과 관련이 있음은 분명하다. 일반적으로 SMA는 아이들에 게서 보이는 활발 한 움직임이 귀찮아지는 시점부터 형성되어 본격적 퇴행 이 일어나는 갱년기부터는 심각해진다(Hanna, 1988). 오 랜 시간 신체활동을 하지 않아 SMA가 지속되면 몸의 구 조는 왜곡되고 기능은 조금씩 마비되는 것이다. 노인에 게 서 흔히 발생하는 운동기능저하 현상은 뇌에서 근육으로 보내는 운동신경계와 그 역으로 진행하는 감각신경계의 손상과 관련이 있는데 이는 모두 의식적 움직임의 감소로 인해 신경생리활동이 줄어들었기 때문에 발생하는 SMA 의 일종이다. 그러면 SMA는 어떠한 신경생리학적 기전에 서 발생하는 것일까?

\section{스트레스 반응과 SMA}

앞에서 언급한대로 SMA는 스트레스와 관계가 깊다. 일반 의료적 관점에서 보면 스트레스는 자극에 대한 몸 의 손상비율이다. 그러나 스트레스 그 자체는 긍정적이 거나 부정적이지 않다. 몸이 어떻게 반응하느냐는 크게 두 가지 측면으로 이야기 할 수 있는데, 하나는 내분비계 의 자극에 대한 생화학적 반응이고 다른 하나는 신경근육 계의 자극에 대한 운동생리적 반응이다. 전자는 스트레 스를 연구한 Selye가 관심을 가졌고 후자는 신경계의 감 각-운동 기능을 몸학적으로 연구한 Hanna의 주 관심사였 다. 물론 이 두 가지 측면이 신경생리학적으로 얽혀 있기 때문에 완전히 분리해서 설명할 수 없지만 여기서 SMA 와 관련된 스트레스 반응은 Hanna의 연구에 초점을 두고 기술하였다.

개인의 삶에 감당하기 버거운 스트레스가 지속될 때 근육은 수축되면서 살아남기 위한 몸의 무장이 시작된다. 이 근육무장이 이완되지 못한 상태로 몸 안에 남게 될 때 처음에는 피로와 경직감이 해당부위에 남지만, 긴장이 더 해지면 통증이 발생하고 나아가서는 감각-운동 간의 소 통이 끊어지는 SMA가 발생하는 것이다. 한편으로는 움직 임의 범주가 제한되고 다른 한편으로는 감각이 점점 무디 어지는 감각운동의 기억상실 현상이 바로 그것이다. 이것 이 처음 발생할 때는 스트레스에 따른 몸의 예민한 반응 을 제어하기 위한 신경생리학적 기제로서 존재하지만 시 간이 가면서 의식을 가두는 창살의 역할을 하면서 감각과 운동의 훼방자로 남게 된다. 말하자면, 근육과 인대 등에 
퍼져 있는 고유수용감각을 마비시키고 수의적 운동을 방 해함으로써 근골격 활동을 위축시킨다. 그 결과, 감각운 동계의 불균형이 발생하고 그것은 곧 몸 전체의 불균형으 로 이어진다. 이렇게 균형을 잃은 상태에서 일어나는 보 상작용으로 자세가 뒤틀어지는 구조의 왜곡이 일어난다.

Hans Selye가 스트레스 반응을 부정적 스트레스인 디스 트레스(distress), 긍정적 반응인 유스트레스(eu- stress) 로 구분한 것에 대하여, Hanna는 디스트레스로 생겨난 자세 의 왜곡을 도피 반응(withdrawal response), 유스트레스로 생겨난 자세의 왜곡은 진행반응(action response)과 관계 가 있다고 주장한다(Hanna, 1988). 가령, 지속적인 디스트 레스로 도피반응을 일으키는 사람의 경우 태아가 신체의 전면을 수축하며 웅크리는 것과 같이 복부근육을 중심으 로 긴장 패턴을 유지하게 되고, 유스트레스로 진행반응 을 자주 일으키게 되면 신체의 후면 근육을 수축시켜 전 만 자세를 유지하는 경향이 있다는 것이다. Hanna는 전자 를 빨간등 반사, 후자를 초록등 반사라고 명명하였다. 이 어 그는 수술이나 사고 또는 극심한 트라우마가 원인이 되어 생겨나는 좌우의 불균형적 뒤틀림은 트라우마 반사 라고 불렀다. 이 세 가지 반사는 우리 몸의 기초 반사와 연 결되어 $\mathrm{SMA}$ 를 유발하고 소마의 왜곡을 초래하게 된다. 예를 들어 척추 전만, 후만, 측만 등이 밖으로 들어난 왜곡 현상이다(Hanna, 김정명역, 2013).

$\mathrm{SMA}$ 는 밖에서 보면 신체가 붕괴되는 퇴행성 변화로 종종 오인되지만 이것은 사실 감각-운동이 하나의 루프 로 연결되어 작용하는 신경계 손상 즉 뇌의 기능적 문제 인 것이다. 때문에 구조의 관점에서 $\mathrm{SMA}$ 를 다루려는 의 사는 결코 이 문제를 근원적으로 해결하지 못하고 외과적 처치를 하거나 진통제나 소염제를 제공하는 수준의 처방 에 머물게 될 뿐이다.

\section{신경계의 기능장애로서의 SMA}

스트레스와 SMA를 신경계의 기능과 연결시켜 보려면 신경계의 구조를 간략하게 이해할 필요가 있다. 신경계 는 구조적으로 구심성(afferent)의 감각신경과 원심성(efferent)의 운동신경으로 나누어진다. 여기서 구심성이란 말단 감각부위에서 일어난 자극이 감각신경을 통해 중추 신경계인 뇌와 척수에 감각정보를 들여온다는 뜻이고 원 심성은 반대로 중추신경계에서 발생한 운동신호가 말단 근육이나 장기에 전달되는 것을 뜻한다. 이렇게 말단 근 육이나 인대에 전달될 때 근수축이 일어나면서 움직임이
실현된다. 감각신경과 운동신경은 이렇게 구조적으로는 둘로 나누어져 있지만 뇌의 중추부에서는 기능적으로는 통합되어 있다. 실제로 감각피질과 운동피질은 뇌에서 좌 우반구를 가로지르며 앞쪽의 운동영역과 뒤쪽의 감각영 역이 연결되어 있고 척수에서는 게재신경(interneuron)에 의해 연결되어 있다(Crossman \& Neary, 2015).

중추신경계에서 스트레스와 깊은 관계를 맺고 있는 부 위는 피질아래 위치하며 감성뇌라도 불리는 변연계이다. 그것은 그 자체로 피드백 되는 수많은 회로들을 갖고 있 으며 각각의 회로는 순간순간의 기분이나 느낌을 모니터 해주고 있다. 우리 자아가 개인적인 내적 감각과 지각을 외부 환경과 의미 있게 연결시키는 경우에는 예외 없이 이 부분을 거친다. 그것은 두뇌의 모든 부분과 소통하는 능력을 가지고 있고 우리 자신을 하나의 개인으로서 인 식하고 세계와 관계를 맺도록 돕는다. 변연계는 편도체 와 시상하부, 해마를 중심으로 외부 위협이나 스트레스에 대한 적응을 주도하고 기억과 학습 등 인지과정에 깊이 연관되어 있어 $\mathrm{SMA}$ 의 발생의 단서를 쥐고 있는 기관이 다. 변연계 내에서 스트레스 반응은 편도체에서 먼저 일 어난다. 그것은 생존 본능에 의해 자신을 보호하는 첨병 이기 때문이다. 심리학자들이 전투-도피 반응(fight- flight response)이라고 부르는 적응반응은 먼저 편도체가 담당 한다(Caldwell, 김정명역, 2007). 이 기관을 통하여 두려움 이라는 감성적 감각정보가 들어와 거기에 적절한 반응을 보이도록 행동을 조율하고 주의력에 관계하며 자신의 기 억을 보조한다. 그것은 두뇌의 여러 부분과 폭넓은 교신 을 담당하는 것은 물론이고 위급 상황에서는 대뇌 시스템 의 상급공정마저 생략하고 독자적으로 작동하는 독보적 위치에 있다. 편도체의 주된 작업은 주로 위협에 대한 반 응이지만 우리는 종종 위협적이 아닌 상황에서도 감정이 격해진다. 무언가를 잃어버리거나 시험시간에 쫓기는 패 닉 상황에도 작동한다. 결국 어떠한 스트레스 상황에도 작동하고 있는 것이다. 하지만 계속되는 스트레스에는 교 감신경 계도 감당이 어렵다. 그것은 짧은 시간에 반응하는 생존 메커니즘이기 때문에 만성적으로 활성화되면 우리 몸에 심각한 결과를 초래하게 된다.

이렇게 몸이 붕괴되는 이유는 우리가 의식하지 못하는 사이에 만성적 스트레스 반응이 신경계를 교란시키기 때 문이다. 교감신경계는 부교감신경계와 더불어 자율신경 계에 구성된 교번 조직으로 서로의 길항작용을 통해 몸을 정상상태로 회복시킨다. 위기상황에는 교감신경계의 호 
르몬 작용에 의해 몸이 긴장되고 수축되었다면 곧 이어 부교감신경계는 심박과 혈압을 떨어뜨리며 몸 전체를 이 완하여 소통을 원활하게 한다. 그러면서 소화기관의 근육 을 자극하여 소화와 배설을 촉진한다. 이렇게 해서 교감 신경계와 부교감신경계의 길항작용은 우리 몸의 바람직 한 항상성을 유지시킨다.

그러나스트레스 반응이 과도하여 우리 몸의 긴장상태 가 지속되면 부교감신경계가 작동하지 않아 안정과 휴식 의 기회가 박탈되고 만성 근수축과 함께 몸의 붕괴가 일 어나는 것이다. 하여 등과 몸의 통증이 만연하고, 면역계 와 심혈관계에 문제가 많이 나타나고 있다. 그리고 심한 경우 종종 삶의 의욕이 떨어지고 디프레스 상태에 빠진다 (Hanna W., 2013). 스트레스 반응이 지속적으로 만성화되 면 항상성을 유지하기에 충분한 부교감신경계의 활성화 가 힘들어지기 때문이다. 이러한 상황에 빠지게 되면 내 분비계, 심혈관계, 면역계 등에 장애가 발생하고 나아가 해마 속 뇌세포의 죽음과 연결되는 기억상실 현상과 더불 어 이른바 노화과정이 시작한다. 이때 오래 묵은 만성 근 수축은 몸 안에 만성적인 통증으로 남아 있기 쉽다. 왜냐 하면 수의적 운동피질의 감각-운동 신경들은 종종 감각 능력의 일정부분이 마비되어 우리 몸의 근육을 통제할 수 없기 때문이다. Thomas Hanna는 바로 이러한 상태를 “ 감각-운동 망각(SMA)”이라고 불렀다(Hanna, 1986). 그 것은 마치 몸의 일부가 자신의 것으로 느껴지지 않거나 전혀 감각을 느낄 수 없는 상태와 같다. 또한 내 몸이 자신 의 통제를 벗어나 있는 것 같은 기분 나쁜 증세를 동반한 다(Hanna, 1990).

\section{몸학적 대안}

지속되는 스트레스 압력에 대해 반응을 멈추는 과정 이 가능한가? 그것은 무의식 영역에서 이루어지는 공정 일 경우는 불가능하다. 그러나 의식적 움직임을 주도하는 피질의 전전두엽과 변연계의 교번 관계를 통하여 이것을 가능하게 만들 수 있다. 이렇게 무의식 안에서 자동 학습 되는 과정을 중단시킬 수 있는 것은 뇌의 가소성 때문이 다. 스트레스 상황에도 과도한 근육 반응을 학습하지 않 는 것은 바로 대뇌의 감각-운동 시스템에 의해서다. 인간 이 자신의 의도를 실현 할 수 있는 신피질 부위를 소유하 고 있다는 것은 SMA를 스스로 해결할 수 있는 비밀을 보 유하고 있는 셈이다. 여기서 감각피질은 안이비설신(眼
耳鼻舌身)을 통하여 우리를 둘러싸고 있는 환경으로부터 정보를 취한다. 또한 우리의 체성감각 시스템은 고유수용 감각들을 통하여 인체 내부의 정보를 우리에 게 전달한다. 이러한 감각정보는 뇌로 이동하기 전 단계에서는 각각 단 절된 것들이지만 어떤 정보도 손실되지 않는다. 뇌는 이 풍부한 데이터를 활용하여 개인적 의미와 복잡한 학습을 위한 새로운 연결을 만들어 나간다. 뇌가 효율적으로 작 동하기 위해서는 그것이 받아들이는 감각-운동 정보가 바탕이 되어 효율적으로 운영되어야 한다. 이들 정보 중 가장 우선적인 것은 당연히 우리의 안전을 위협하는 것이 다. 이 때문에 감각운동 정보는 대뇌로 보내지기 전에 편 도체와 바로 그 앞방인 시상으로 간다. 이후 정보의 우선 수준을 결정하고 대뇌는 계획을 하고 말초신경계로 메시 지를 보내는 기능을 수행하여 실제로 근육과 사지를 공간 에서 움직일 수 있도록 만든다. 움직임을 계획하고 실행 하기 위해서 운동피질은 소뇌로부터 특별한 지원을 받는 다. 소뇌는 학습된 기술적 움직임을 타이밍을 통해 조정 하는 숙련 운동기능을 수행한다. (Hanna, 1998, 2002).

그러나 소뇌는 이 프로그램을 직접 수행할 수 없다. 운 동피질이 제 때 필요한 것을 사용할 수 있도록 도울 뿐이 다. 종종 우리의 운동 피질은 새로운 운동 프로그램을 창 조하는 것보다 소뇌에 저장된 프로그램 사용을 선호한다. 저장되어 있는 프로그램이 더 익숙하고 편하기 때문이다. 그러나 감각-운동 망각이 일어나 있는 SMA 상태에서는 소뇌에 저장된 프로그램을 사용해서는 안 된다. 너무 익 숙하여 움직임의 감각이 인지되기 어렵기 때문이다. 하여 운동피질로부터 새로운 운동 프로그램을 만들 필요가 있 다. 이른 바 재학습이 요구된다. 그래서 모든 소매틱 프로 그램들은 SMA를 의식의 영역으로 드러내기 위해서 처음 운동을 배울 때처럼 신피질을 사용하면서 주의력을 가지 고 느린 움직임을 실행하게 마련이다.

\section{몸적 학습(somatic learning)}

$\mathrm{SMA}$ 를 의식적으로 다루는 과정을 Hanna는 몸적 학습 (somatic learning)이라고 불렀다(Hanna, 1986). 사람들은 열심히 운동 하지만 이 문제가 쉽게 해결되지 않는 이유 는 자신에게 익숙한 숙련된 방식에 집착하고 있기 때문이 다. 몸적 학습은 감각-운동 피드백 루프를 사용하여 아주 천천히 그리고 정교하게 몸의 기능적 시스템을 다시 프로 그램 한다. 악기를 연주하거나 전문 운동선수가 고난도의 운동 기술을 학습하는 것과 달리, 몸적 학습은 기계적으 
로 이루어지지 않는다. 이 과정에서 우리가 움직임에 대 한 암기는 중요하지 않다. 순간의 움직임의 모든 면을 의 식적으로 체험하는 것이 중요하다.SMA를 극복하기 위한 몸적 학습은 운동신경을 흥분시키거나 자제시키는 직간 접적인 피질-척추간 메시지를 통해 일어난다. 우리 근육 자체에는 의지가 없다. 피질-척추 간 운동 경로의 메시지 는 뇌간을 오르내리면서 근육에 게 어떻게 행동할지를 말 해준다. 흥분과 억제의 메시지는 척수로부터 근육섬유까 지 뻗어있는 알파 운동신경에 의해 연결된다. 감마 운동 신경은 척수로부터 근육방추로 뻔어 나와 있다. 일반적으 로 운동신경은 근육수축의 초기휴면수준의 프로그램을 가지고 있지만 심한 $\mathrm{SMA}$ 의 경우 그것이 작동하지 않아 근육을 이완시킬 수 없는 경우도 많다(Criswell, 1989). 하 여 우리가 근육을 이완시키더라도 근육 속 잔여긴장이 여 전히 남게 된다. SMA 상태에서는 근육의 기시점(origin) 과 유착(insertion)의 표준비율을 넘어서는 강도로 근육 세포로부터 신경세포에 게 강하고 실효성 있는 감각 피드 백을 공급할 필요가 있다. 이렇게 되면 세트 포인트를 초 과할 정도로 온도가 올라가면 자동으로 꺼지는 온도조절 장치와 같이 운동신경은 근수축을 위한 발화(firing)를 멈 추고 저절로 이완하기 시작한다(Hanna, 김정명 역, 2013; Hanna, 1990).

Thomas Hanna는 Feldenkrais 이외에도 이른 바 몸학적 관점을 가지고 $\mathrm{SMA}$ 를 해결했던 사람들에 대하여 연구 하면서 이것들이 공통적으로 가지고 있는 감각-운동 회 로와 연결된 뇌의 기능적 작용에 주목하였다. 그리고 우 리가 받는 자극에 대하여 제대로 해석하고 반응함으로써 스트레스에 적절히 대처하기만 한다면 이러한 질환들 중 에 어떤 것도 발생할 이유가 없다고 본 것이다. 우리의 의 도와는 관계없이 자율신경계를 통하여 저절로 학습되는 상황이라고 하더라도 적극적 휴식(active rest)과 함께 환 경 안의 자극을 공포나 두려움으로 학습하지 않도록 적 절히 해석하고 반응한다면 우리 몸의 항상성은 회복될 수 있다(Caldwell, 김정명역, 2007). 이것이 나이에 관계없 이 기능적으로 건강하게 사는 비결이다. Hanna는 실제로 이러한 점에 착안하여 느린 동작으로 이루어지는 8 가지 종류의 체조를 개발하고 '노화의 신비'(Myth of Aging) 라는 이름을 붙였다(Hanna, 1988). 나아가 그는 F. Matthias Alexander의 진행과정(means-whereby; MWB)테크닉과 Feldenkrais의 기능통합(functional integration; FI)의 바탕 아래 본인이 개발한 기지개 반응(pandiculation response;
$\mathrm{PR}$ )을 이용하여 효과적으로 SMA를 회복시키는 임상운 동 프로그램을 개발하기에 이른다. 이 프로그램은 그의 부인 Eleanor Criswell 등에 의해 신경생리학적으로 정제 되어 오늘날 HSE(Hanna Somatic Education)이라는 이름으 로 알려지고 있다.

\section{Alexander의 진행과정}

알렉산더 테크닉은 SMA의 해결에 서막을 연 최초의 몸학적 기법이었다. 알렉산더가 이 기법을 개발할 당시 에는 SMA라는 증세의 개념에 대한 이해조차 없었다. 다 만 그가 셰익스피어 낭송가로서 무대 위에서 명성을 얻을 무렵 문제가 생긴 목소리를 스스로 고치는 과정에서 발견 한 잘못된 습관이 단서가 되었다. 우리 대부분은 어떠한 이유로든 다소 간의 잘못된 습관 속에 살고 있다. 대개의 경우 그것을 인지하지도 못하지만 알더라도 고칠 생각을 하지 않고 살아간다. 그러나 만약 그것이 일상생활이나 생계에 지장을 주고 있음을 알게 된다면 그것을 바로 고 치려 할 것이다. 알렉산더의 경우도 생업에 지장을 줄만 큼 문제가 된 것이다. 그러나 그는 문제를 성급히 수정하 려고 시도하기 보다는 문제의 원인이 어디에 있는지 알아 보는 데 초점을 맞추었다. 성 대조직에는 문제가 없음을 확 인한 알렉산더는 단순한 바이오피드 백 도구인 거울을 이 용하여 무대에서 발성을 시도할 때의 자신의 몸의 변화를 면밀히 관찰하기 시작했다. 충분한 자가 실험이 있은 후 발성 시 자신의 자세가 틀어지며 목 부위가 압박되고 있 음을 발견하게 된다. 이것은 거의 무의식 속에서 이루어 지는 전형적인 근수축임을 확인하면서부터 그의 몸학적 작업은 시작되었다(최현묵 \& 백희숙, 2016).

알렉산더 테크닉의 시작점은 이렇게 목적을 자제(inhibition)하고 그 진행과정(means-whereby; MWB)에 스스로 몰입함으로써 무의식 속에 들어 있던 수축부위를 찾아낸 작업이었다. 수축부위를 찾아낸 후에도 그는 자세를 교정 하여 똑바로 서는 목적에 마음을 두었다면 이 문제를 해 결하기 어려웠을 것이다. 그는 소리를 낼 때 수축되는 목 부위를 비롯하여 머리, 어깨, 가슴 등 몸의 관련 부위 하나 하나의 진행과정을 면밀히 관찰함으로써 발성에 적합한 자세로 회복 될 수 있었다(Brown, 2017). Hanna Somatics에 서는 의도적 움직임을 계획하고 해당 근육에 수의적 움직 임의 메시지를 전달할 때, 운동피질에 매순간 감각 피드 백을 주기 위해 유사한 방식으로 이 테크닉을 이용하고 있다. HSE 전문가가 손으로 알려 주는 이 새로운 감각 정 
보에 의해 내담자의 무의식 속에 들어 있던 SMA가 인지 되기 시작한다(Hanna, E. C., 1998, 2002).

\section{Feldenkrais의 기능통합}

기능통합(FI)은 Feldenkrais의 수기 테크닉으로 그의 유 도 경험에서 나온 것이다. 한 마디로 이것은 근육의 경련 이나 수축을 이완시키기 위하여 힘의 저항을 사용하는 원 리다. 유도에서 상대가 한쪽 방향으로 힘을 쓰면 반대방 향으로 저항하다가 갑자기 상대와 같은 방향으로 방향을 바꾸어 힘을 쓰면 상대가 맥없이 따라가게 되는 원리가 있다. Feldenkrais는 이 유도의 원리를 응용하여 수축되었 던 근육을 이완하는데 사용하였다. 이미 수축되어 있는 근육을 이완하기 위해서 수축되어 있는 부분을 강제로 스 트레치 시키게 되면 수축력이 더욱 강화된다. 따라서 수 축되는 방향으로 '의도적' 수축을 가하게 되면 무의식 상태에서 수축하고 있던 근육이 이 의도적 움직임 때문에 이완되기 시작하는 것이다. Feldenkrais가 이야기 한 것처 럼 “여러분이 어떤 근육에 일을 시키면 그 근육은 스스 로 하던 작업을 멈춘다(김정명, 2016).” 이렇게 우리 몸 에서 무의식적으로 수축된 근육의 이완은 뇌의 작용에 의 한 감각-운동 피드백 프로세스에서 일어난다. 하여 무의 적으로 수축된 근육으로 인한 $\mathrm{SMA}$ 는 의도적인 움직임에 의해 의식의 영역에 드러나는 것이다.

Hanna는 Feldenkrais의 FI 기법을 운동거울보기(kinetic mirroring; KM) 라고 부르며 이를 이용하여 그의 HSE의 기 본 테크닉을 발전시켰다. FI에는 그 이외에도 Feldenkrais 의 제자였던 Yochanan Rywerent가 짝운동(conjugate movement)이라고 부르는 테크닉들이 포함되어 있는데 이것은 고도의 인공두뇌학적 접근으로 몸과 마음의 연결선상에 서 나타나는 신경생리학적 기제를 이용하는 테크닉이다. 이 테크닉은 우리 몸의 말단(distal) 부위를 움직이는 관절 에 통증이 느껴지며 움직임을 제한하는 저항을 만날 때 그 저항을 무리하게 이겨내려고 스트레치하기 보다 같은 관절의 중심(proximal) 부위의 움직임을 반복하며 통증을 해소하는 방법을 말한다(Rywerant, 2008). 이는 어떤 움직 임을 할 때 내면에서 일어난 통증과 저항의 예측 때문에 마비되어 있는 SMA를 회복하기 위한 방식으로 FI에서는 물론 HSE에서도 널리 활용되고 있다.

\section{Hanna의 기지개 반응}

기지개 반응(pandiculation response; PR)은 모든 척추동
물에 게서 일어나는 신체반응으로 주로 깨어날 때 의도적 으로 수의적 근육을 수축하는 과정에서 일어난다. 가령, 개나 고양이가 기지개를 켜는 동안 수의피질을 효과적으 로 기능하게 하면서 정상적인 감각과 운동을 준비한다. 이러한 기지개 반응은 일반적으로 반동을 이용한 스트레 치와는 달리 피질을 깨우기 위한 원초적 감각-운동 패턴 이다. 하여 HSE 전문가들은 자신의 수기요법으로 감각 피 드백에 초점을 맞추는 Feldenkrais 전문가들과는 달리 학 습자로 하여금 망각된 근육의 수축을 만들어내도록 유도 함으로써 학습자 자신이 감각 피드백을 만들어내도록 돕 는 방식이다(김정명, 2016).

$\mathrm{PR}$ 의 효과는 실제로 가공할 만큼 정확하다. 심지어 40 년 이상 무의식 속에 수축되어 있던 근육들까지 이완되고 세션이 끝난 후에도 재수축이 일어나지 않는 등 SMA의 확실한 해결책으로 등장했다. 이에 Hanna는 의료계에 자 신의 소매틱스를 새로운 헬스케어 혁명을 일으킬 수 있는 임상학문으로서 제시하고 있다(Hanna, 1990). 그러나 학 습자가 $\mathrm{PR}$ 을 정확하게 실시할 수 있도록 학습하는 일은 그리 간단하지 않다. 그것은 예술이라고 불릴 만큼 고난 도 테크닉을 수반하며 전문가와 학습자의 긴밀한 신뢰와 협력을 요구한다. 그러나 일단 학습되고 나면 SMA의 해 결은 물론 학습자와 전문가가 함께 자율적 움직임이 가져 다주는 놀라운 결과를 삶 속에서 향유할 수 있다.

\section{결 론}

각종 만성질환의 원인으로 지목되는 SMA를 발견하게 된 경로를 추적하고 그 신경생리학적 기전을 확인한 결 과, SMA는 스트레스를 주창한 Hans Selye의 일반적응 증 후와 Feldenkrais의 임상적 기법에 영향을 받아 신경계를 연구하던 Thomas Hanna가 발견한 신경생리적 병변으로 나타났다. 이것은 무의식 속에 들어가 있는 만성근수축인 관계로 삼자관찰을 전문으로 하는 의료인들이 다루기 힘 든 질환으로 의료계에서는 국부근육질환(regional muscular illness)으로 불리기도 한다. 신경생리학적으로 SMA는 만성적 스트레스 반응이 신경계를 교란하는 과정에서 발 생하고 그 상황이 지속될 때는 무의식의 영역에서 감각운동 기능의 훼방자로 남아 고유수용감각을 마비시키고 근골격 활동을 위축시켜 만성통증과 함께 인간 움직임의 범주를 크게 제한할 뿐 아니라 신체의 구조적 변형을 초 래하는 원인으로 작용하고 있다. 
$\mathrm{SMA}$ 의 정체에 대한 신경생리학적 규명과는 별개로 Thomas Hanna가 그 해결책을 찾는 과정에서 찾은 몸학적 대안은 감각-운동 회로에서 발생하는 다양한 신경생리학 적 기제를 활용한 몸적 학습(somatic learning)이었다. 이 것을 찾는 과정에서 Hanna는 Matthias F. Alexander의 진 행과정(MWB) 기법, Moshe Feldenkrais의 기능통합(FI) 등 주요 기법을 활용하여 SMA해결에 가장 효과적으로 나타 나는 자신만의 기법인 기지개 반응(PR) 기법을 만들기에 이른다. 그는 세상을 떠나기 직전 자신의 기법이 의료적 으로도 성공할 수 있으리라는 확신 아래 몸학을 헬스케 어를 주도할 새로운 임상운동 기법이자 학문으로 제시하 였다. 그가 살아 있는 동안 가르쳤던 수 천 명의 내담자들 과 제자들은 $\mathrm{HSE}$ 의 기지개 반응이 여러 가지 만성질환의 근원인 $\mathrm{SMA}$ 를 치유하는 최상의 기법임을 체험적으로 알 고 있다.

그러나 오늘날의 의료체계는 무엇보다 삼자관점의 실 증성을 기반으로 질병을 진단하고치료하는 만큼 몸학 바 탕의 운동 전문가는 $\mathrm{SMA}$ 를 정확히 찾아내고 그 성과를 명확히 예측할 수 있는 임상운동 과정을 전문적 훈련을 받은 사람이어야 할 것이다. 이를 위해서는 전문가나 학 습자의 체험적 데이터가 신뢰성을 확보하기 위한 임상적 노력을 더욱 필요할 것이다. 또한 우리나라의 보건 의료 계도 신경과학적 기반의 다양한 소마교육에 깊은 관심을 기울여야 할 것이다. 이러한 노력의 결과 선진국에서는 의료인들이 나서서 국부근육질환 등 의료적 처치가 곤란 한 환자들에 게 수술이나 약물보다는 몸학적 접근을 권하 는 사례가 늘고 있고 이것은 기존 의료계의 과부화 상태 를 해소하는데 도움을 주고 있다. 다만, 소마교육이 일자 관점을 중심으로 삼자정보를 통합시키는 과정인 만큼, 인 간의 몸을 다루는 새로운 통합적 임상체계가 몸학을 기초 로 새롭게 형성되어야 할 것이다.

\section{Acknowledgements}

이 논문은 2016년도 명지대학교 교내연구비 지원으로 연구 되었음.

\section{Conflicts of Interest}

The authors declare no conflict of interest.

\section{References}

김정명 (2016). 예술지성: 소마의 논리, 서울: 명지 대학교 출판부. 도소은 (2017). 휄든크라이스 방식: 움직임을 통한 심신학습, 지 금여기, 미내사클럽, 97-104.

최현묵 \& 백희숙 (2016). 내 몸의 건강사용법: 알렉산더 테크닉, 서울: 무지개다리넘어.

Brown, R. ed. (2017). F.M. 알렉산더의 가르침(원제: Authorized Summaries of F.M. Alexander's Four Books, 1992), 최현묵 \& 백희숙 역, 서울: 무지개다리넘어.

Caldwell, C. (2007). 몸으로 떠나는 여행(원제: Getting our bodies back, 1996), 김정명 역, 서울: 한울.

Criswell, E. (1989). How yoga works: An introdeuction to Somatic Yoga, Novato, California: Freeperson Press.

Crossman, A. R. \& Neary, D. (2015) Neuroanatomy (5th), Churchill Livingstone: Elsvier.

Feldenkrais, M. (1990). Awareness through movement, California, San Francisco: HarperCollins.

Hanna, T. (2013). 부드러운 움직임을 찾아(원제: The body of life: Creating new pathway for sensory awareness, 1993), 김정명 역, 소피아.

Hanna, E. C. (2002). Neurophysiology lecture(1-5), unpublished lecture note, Novato Institute.

Hanna, E. C. (1998). Draft of HSE neurophysiological lectures, unpublished interview material.

Hanna, T. (1990). Clinical Somatic Education: A new discipline in the field of health care, Somatics (Autumn-Winter), 4-10.

Hanna, T. (1988). Somatics: Reawakening the mind's control of movement, flexibility, and health, Da Capo Press.

Hanna, T. (1986). What is Somatics?, Somatics(Spring/Summer), 4-8.

Hanna, T. (1979). The body of life: Creating new pathway for sensory awareness, Rochester, Vermont: Healing Arts Press.

Hanna, T. (1970). Bodies in revolt: A primer of somatic thinking. Novato California: Freeperson Press.

Hanna, W. (2013). Cronic stress, and sensory-motor amnesia: Counteracting cumulative inhibitions to freedom of movement, Somatics, 17(1), 52-55.

Rosch, P. J. (2017). Reminiscences of Hans Selye, and the birth of stress, American Institute of Stress Homepage, www.stress. org

Rywerant, Y. (2008). Corollary discharge: The forgotten link, Novato 
California: Freeperson Press.

Selye H. (1978). Stress of life. New York: McGrawHill. pp. XV-XIII., XVI. 